\title{
Halobacterium jilantaiense sp. nov., a halophilic archaeon isolated from a saline lake in Inner Mongolia, China
}

\author{
Yong Yang, ${ }^{1,2}$ Heng-Lin Cui, ${ }^{1,2}$ Pei-Jin Zhou ${ }^{1}$ and Shuang-Jiang Liu ${ }^{1}$ \\ ${ }^{1}$ State Key Laboratory of Microbial Resources, Institute of Microbiology, Chinese Academy of \\ Sciences, ZhongGuanCun, Haidian, Beijing 100080, PR China \\ ${ }^{2}$ Graduate School of Chinese Academy of Sciences, Beijing 100049, China
}

Correspondence

Shuang-Jiang Liu

shuangjiang@hotmail.com

\begin{abstract}
A novel halophilic archaeon, $N G 4^{\top}$, was isolated from Jilantai salt lake in Inner Mongolia, China. The taxonomy of strain NG4 ${ }^{\top}$ was studied by polyphasic methods. Strain NG4 ${ }^{\top}$ grew at $\mathrm{pH} 5 \cdot 5-8 \cdot 5$ and at a temperature of $22-55^{\circ} \mathrm{C}$. It was chemo-organotrophic, aerobic and required concentrations of $2 \cdot 7-5 \cdot 2 \mathrm{M} \mathrm{NaCl}$ and $0 \cdot 05-0 \cdot 3 \mathrm{M} \mathrm{Mg}^{2+}$ for growth. Cells were Gram-negative, slender rods. Colonies on agar plates containing $25 \%(\mathrm{w} / \mathrm{v})$ total salts were red, elevated and round. According to $16 \mathrm{~S}$ rRNA gene sequence similarity, strain $\mathrm{NG} 4^{\top}$ was phylogenetically related to Halobacterium salinarum DSM $3754^{\top}(98 \cdot 2 \%)$ and Halobacterium noricense $A 1^{\top}(97 \cdot 3 \%)$. The DNA G $+\mathrm{C}$ content was 64.2 mol\%. DNA-DNA relatedness values with $\mathrm{Hbt}$. salinarum DSM $3754^{\top}$ and $\mathrm{Hbt}$. noricense $\mathrm{A} 1^{\top}$ were 47 and $35 \%$, respectively. The polar lipids of strain NG4 ${ }^{\top}$ consisted of phosphatidylglycerol, methylated phosphatidylglycerol phosphate, phosphatidylglycerol sulfate, triglycosyl diether, sulfated triglycosyl diether and sulfated tetraglycosyl diether. It was concluded that strain $\mathrm{NG} 4^{\top}$ represents a novel species of the genus Halobacterium, for which the name Halobacterium jilantaiense sp. nov. is proposed. The type strain is NG4 ${ }^{\top}$ $\left(=\right.$ CGMCC $1.5337^{\top}=$ JCM $\left.13558^{\top}\right)$.
\end{abstract}

Members of the genus Halobacterium (Grant, 2001) are obligately aerobic and heterotrophic and live in highly saline environments such as salt lakes and salterns. Several former members of the genus Halobacterium have been excluded from the genus, based on distant relationships as determined by phylogenetic analysis (McGenity \& Grant, 1995). Currently, the genus Halobacterium contains two recognized species: Halobacterium salinarum (Ventosa \& Oren, 1996; Grant, 2001) and Halobacterium noricense (Gruber et al., 2004).

Strain $\mathrm{NG}^{\mathrm{T}}$ was isolated from the salt lake of Jilantai $\left(105^{\circ}\right.$ $42^{\prime}$ E $39^{\circ} 45^{\prime} \mathrm{N}$ ) in Inner Mongolia, China, by enrichment and subsequent plating on agar medium containing the following ingredients $\left(\mathrm{g} \mathrm{l}^{-1}\right)$ : Casamino acids, $7 \cdot 5$; yeast extract, $10 \cdot 0 ; \mathrm{MgSO}_{4} .7 \mathrm{H}_{2} \mathrm{O}, 20 \cdot 0$; trisodium citrate, $3 \cdot 0$; $\mathrm{KCl}, 2 \cdot 0 ; \mathrm{FeSO}_{4} .7 \mathrm{H}_{2} \mathrm{O}, 0 \cdot 05 ; \mathrm{NaCl}, 200 ;$ agar, $15(\mathrm{pH}$ adjusted to $7 \cdot 4$ with $1 \mathrm{M} \mathrm{NaOH})$. The strain grew at a temperature range of $22-55^{\circ} \mathrm{C}$ (optimum $40{ }^{\circ} \mathrm{C}$ ) and at a $\mathrm{pH}$ range of $5 \cdot 5-8 \cdot 5$ (optimum $7 \cdot 0-7 \cdot 5$ ). Routine cultivation was conducted at $40^{\circ} \mathrm{C}$ and $\mathrm{pH} 7 \cdot 4$. Strain $\mathrm{NG} 4^{\mathrm{T}}$ required

The GenBank/EMBL/DDBJ accession number for the 16S rRNA gene sequence of strain NG4 ${ }^{\top}$ is DQ256409.

A two-dimensional thin-layer chromatograph of polar lipids extracted from strain $N G 4^{\top}$ is available as supplementary material in IJSEM Online.
$2 \cdot 7-5 \cdot 2 \mathrm{M} \mathrm{NaCl}$ (optimum 3.1-3.5 $\mathrm{M}$ ) and $0 \cdot 05-0 \cdot 3 \mathrm{M}$ $\mathrm{MgSO}_{4}$ (optimum $0 \cdot 1-0 \cdot 2 \mathrm{M}$ ) for growth.

Phenotypic tests were performed according to the proposed minimal standards for the description of new taxa in the order Halobacteriales (Oren et al., 1997). Cell motility and morphology were examined by phase-contrast and transmission electron microscopy of exponentially growing liquid cultures. Gram staining was carried out as described by Dussault (1955). Colony morphology was observed by growth on agar medium after incubation at $40{ }^{\circ} \mathrm{C}$ for 7 days. Anaerobic growth was tested in the presence of $5 \mathrm{~g}$ potassium nitrate $1^{-1}$, L-arginine and DMSO in filled, stoppered tubes. Tests for catalase and oxidase activity and hydrolysis of starch and of Tweens 20, 40,60 and 80 were performed as described previously (Gonzalez et al., 1978). Nitrate reduction, $\mathrm{H}_{2} \mathrm{~S}$ formation, indole formation and the utilization of sugars, alcohols, amino acids and organic acids were examined as described by Oren et al. (1997). Phospholipids and glycolipids were separated by thin layer chromatography on silica gel plates $(10 \times 10 \mathrm{~cm})$ and were analysed according to the method of Xin et al. (2001).

DNA base composition was determined by thermal denaturation $\left(T_{\mathrm{m}}\right)$ (Marmur \& Doty, 1962). The 16S rRNA gene was amplified by PCR using the halophilic archaea-specific primers $5^{\prime}$-TTCCGGTTGATCCTGCC-3' 


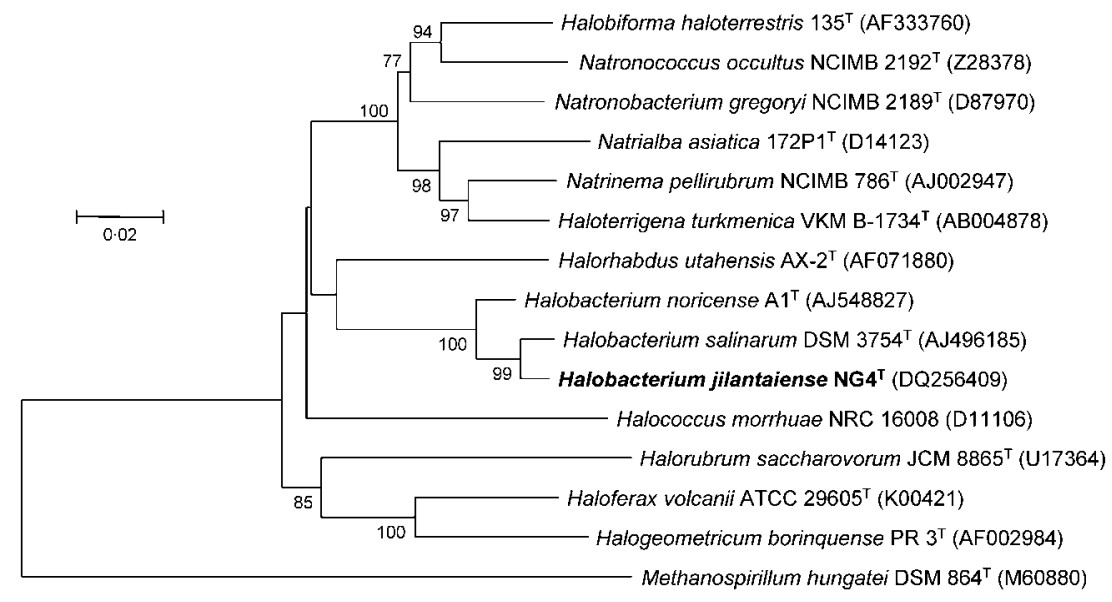

Fig. 1. Phylogenetic tree based on $16 \mathrm{~S}$ rRNA gene sequences showing the relationship between strain $\mathrm{NG} 4^{\top}$, other members of the genus Halobacterium and members of other selected genera of the family Halobacteriaceae. Bootstrap values (\%) are based on 1000 replicates and are shown for branches with more than $70 \%$ bootstrap support. Bar, 0.02 expected changes per site.

and $5^{\prime}$-AAGGAGGTGATCCAGCC-3'. The PCR product was sequenced using an $A B I$ BigDye 3.1 sequencing kit (Applied Biosystems) and an automated DNA sequencer (model ABI 3730; Applied Biosystems). DNA-DNA hybridization of strain $\mathrm{NG}^{\mathrm{T}}$ to the type strains of $\mathrm{Hbt}$. salinarum and Hbt. noricense was performed using the method of De Ley et al. (1970), as modified by Huß et al. (1983). A phylogenetic tree (Fig. 1) was constructed by the neighbour-joining method with Kimura's two-parameter calculation model in MEGA version 3.1 (Kumar et al., 2004).

Results from BLAST searches based on 16S rRNA gene sequence similarities indicated that strain $\mathrm{NG}^{\mathrm{T}}$ was related phylogenetically to Hbt. salinarum DSM $3754^{\mathrm{T}}$ $(98 \cdot 2 \%)$ and Hbt. noricense $\mathrm{Al}^{\mathrm{T}}(97 \cdot 3 \%)$. Strain $\mathrm{NG}^{\mathrm{T}}$ contained $\mathrm{C}_{20} \mathrm{C}_{20}$ derivatives of phosphatidylglycerol (PG), methylated phosphatidylglycerol phosphate (PGP-Me), phosphatidylglycerol sulfate (PGS), triglycosyl diether (STGD-1), sulfated triglycosyl diether (S-TeGD) and sulfated tetraglycosyl diether (TGD-1), similar to Hbt. salinarum (see Supplementary Fig. S1 available in IJSEM Online). The lipid composition, physiological properties (see species description below) and DNA characteristics indicated that $\mathrm{NG}^{\mathrm{T}}$ was a member of the genus Halobacterium. The DNA G $+\mathrm{C}$ content was $64 \cdot 2 \mathrm{~mol} \%$. DNA-DNA relatedness values between strain NG4 ${ }^{\mathrm{T}}$ and Hbt. salinarum DSM $3754^{\mathrm{T}}$ and Hbt. noricense $\mathrm{Al}^{\mathrm{T}}$ were 47 and $35 \%$, respectively. Moreover, strain NG4 ${ }^{\mathrm{T}}$ was distinguishable from Hbt. salinarum DSM $3754^{\mathrm{T}}$ and Hbt. noricense $\mathrm{Al}^{\mathrm{T}}$ in phenotypic and physiological properties (Table 1).

Based on these results, it was concluded that strain NG4 ${ }^{\mathrm{T}}$ represents a novel species of the genus Halobacterium, for which the name Halobacterium jilantaiense sp. nov is proposed.

Table 1. Differentiation of strain $N G 4^{\top}$ from other members of the genus Halobacterium

Data for Hbt. salinarum and Hbt. noricense were obtained from Grant (2001) and Gruber et al. (2004),

respectively. ND, No data available.

\begin{tabular}{|lccc|}
\hline Characteristic & Hbt. salinarum & Hbt. noricense & NG4 $^{\mathbf{T}}$ \\
\hline Cell morphology & Small rods & Irregular rods & Slender rods \\
Pigmentation & Red & Light red & Red \\
Optimum $[\mathrm{NaCl}]$ for growth $(\mathrm{M})$ & $3 \cdot 5-4 \cdot 5$ & $2 \cdot 5-3 \cdot 0$ & $3 \cdot 1-3 \cdot 5$ \\
Optimum $\left[\mathrm{MgCl}_{2}\right]$ for growth $(\mathrm{M})$ & $0 \cdot 05-0 \cdot 1$ & $0 \cdot 6-0 \cdot 9$ & $0 \cdot 1-0 \cdot 2$ \\
Temperature range for growth $\left({ }^{\circ} \mathrm{C}\right)$ & $20-55$ & $28-50$ & $22-55$ \\
Optimum growth temperature $\left({ }^{\circ} \mathrm{C}\right)$ & 50 & 45 & 40 \\
pH range for growth & $5 \cdot 5-8 \cdot 0$ & $5 \cdot 2-7 \cdot 0$ & $5 \cdot 5-8 \cdot 5$ \\
Oxidase & + & - & + \\
Urease & - & ND & + \\
Esterase $\left(\mathrm{C}_{4}\right)$ & - & - & - \\
Nitrate reduced & + & - & - \\
Gelatin liquefaction & + & - & + \\
Anaerobic growth with DMSO & + & $54 \cdot 5$ & + \\
DNA G $+\mathrm{C}$ content $(\mathrm{mol} \%)$ & $67 \cdot 1-71 \cdot 2$ & & $64 \cdot 2$ \\
\hline
\end{tabular}




\section{Description of Halobacterium jilantaiense sp. nov.}

Halobacterium jilantaiense (ji.lan.tai.en'se. N.L. neut. adj. jilantaiense pertaining to Jilantai salt lake, where the type strain was isolated).

Cells are slender rods $(0 \cdot 5-1 \cdot 0 \times 1 \cdot 0-3 \cdot 0 \mu \mathrm{m})$ and Gramnegative. Colonies on agar plates containing $25 \%(\mathrm{w} / \mathrm{v})$ total salts are red, elevated and round. Growth is chemoorganotrophic and aerobic; it occurs at $2 \cdot 7-5 \cdot 2 \mathrm{M} \mathrm{NaCl}$ and $0 \cdot 05-0 \cdot 3 \mathrm{M} \mathrm{Mg}^{2+}$ at $\mathrm{pH} 5 \cdot 5-8 \cdot 5$ and at $22-55^{\circ} \mathrm{C}$. Optimal $\mathrm{NaCl}$ concentration, $\mathrm{Mg}^{2+}$ concentration, $\mathrm{pH}$ and temperature for growth are $3 \cdot 1-3 \cdot 5 \mathrm{M}, 0 \cdot 1-0 \cdot 2 \mathrm{M}, \mathrm{pH} 7 \cdot 0-7 \cdot 5$ and $40{ }^{\circ} \mathrm{C}$, respectively. Catalase- and oxidase-positive. Grows anaerobically in the presence of L-arginine, nitrate and DMSO. Nitrate reduction to nitrite is observed and $\mathrm{H}_{2} \mathrm{~S}$ is produced from cysteine. Indole formation is positive. Tween 80 and starch are not hydrolysed. Casein and gelatin are hydrolysed. Amino acids are required for growth. Starch is not hydrolysed. Glucose, galactose, sucrose, maltose, fructose, sorbose, xylose, mannose, lactose, D-ribose, mannitol and sorbitol are not utilized in 7-10 days. Glycerol is utilized without acid production. Susceptible to anisomycin and novobiocin. Resistant to penicillin, ampicillin, rifampicin, chloramphenicol, gentamicin, kanamycin, streptomycin, tetracycline, bacitracin and erythromycin. Cells contain $\mathrm{C}_{20} \mathrm{C}_{20}$ derivatives of PG, PGP-Me, PGS, S-TGD-1, $\mathrm{S}-\mathrm{TeGD}$ and TGD-1. The DNA G+C content is $64 \cdot 2 \mathrm{~mol} \%$.

The type strain, NG4 $4^{\mathrm{T}}\left(=\mathrm{CGMCC} 1.5337^{\mathrm{T}}=\mathrm{JCM} 13558^{\mathrm{T}}\right.$ ), was isolated from Jilantai salt lake in Inner Mongolia, China.

\section{Acknowledgements}

This work was supported by a grant from the Ministry of Science and Technology (2004CB719601). We are grateful to Ms Claudia Gruber for kindly providing the type strain of Hbt. noricense. We express our thanks to Professor W.-Y. Zhuang at the Institute of Microbiology (Beijing) for help with nomenclature.

\section{References}

De Ley, J., Cattoir, H. \& Reynaerts, A. (1970). The quantitative measurement of DNA hybridization from renaturation rates. Eur J Biochem 12, 133-142.

Dussault, H. P. (1955). An improved technique for staining halophilic bacteria. J Bacteriol 70, 484-485.

Gonzalez, C., Gutierrez, C. \& Ramirez, C. (1978). Halobacterium vallismortis sp. nov. An amylolytic and carbohydrate-metabolizing extremely halophilic bacterium. Can J Microbiol 24, 710-715.

Grant, W. D. (2001). Genus I. Halobacterium Elazari-Volcani 1957, $207^{\mathrm{AL}}$ emend. Larsen and Grant 1989, 2222. In Bergey's Manual of Systematic Bacteriology, 2nd edn, vol. 1, pp. 301-305. Edited by D. R. Boone, R. W. Castenholz \& G. M. Garrity. New York: Springer.

Gruber, C., Legat, A., Pfaffenhuemer, M., Radax, C., Weidler, G. W., Busse, H.-J. \& Stan-Lotter, H. (2004). Halobacterium noricense sp. nov., an archaeal isolate from a bore core of an alpine Permian salt deposit, classification of Halobacterium sp. NRC-1 as a strain of Hbt. salinarum and emended description of Hbt. salinarum. Extremophiles 8, 431-439.

Huß, V. A. R., Festl, H. \& Schleifer, K. H. (1983). Studies on the spectrometric determination of DNA hybridization from renaturation rates. Syst Appl Microbiol 4, 184-192.

Kumar, S., Tamura, K. \& Nei, M. (2004). MEGA3: integrated software for molecular evolutionary genetics analysis and sequence alignment. Brief Bioinform 5, 150-163.

Marmur, J. \& Doty, P. (1962). Determination of the base composition of deoxyribonucleic acid from its thermal denaturation temperature. J Mol Biol 5, 109-118.

McGenity, T. J. \& Grant, W. D. (1995). Transfer of Halobacterium saccharovorum, Halobacterium sodomense, Halobacterium trapanicum NRC 34021 and Halobacterium lacusprofundi to the genus Halorubrum gen. nov., as Halorubrum saccharovorum comb. nov., Halorubrum sodomense comb. nov., Halorubrum trapanicum comb. nov., and Halorubrum lacusprofundi comb. nov. Syst Appl Microbiol 18, 237-243.

Oren, A., Ventosa, A. \& Grant, W. D. (1997). Proposed minimal standards for description of new taxa in the order Halobacteriales. Int $J$ Syst Bacteriol 47, 233-238.

Ventosa, A. \& Oren, A. (1996). Halobacterium salinarum nom. corrig., a name to replace Halobacterium salinarium (Elazari-Volcani) and to include Halobacterium halobium and Halobacterium cutirubrum. Int J Syst Bacteriol 46, 347.

Xin, H., Itoh, T., Zhou, P., Suzuki, K. \& Nakase, T. (2001). Natronobacterium nitratireducens sp. nov., a haloalkaliphilic archaeon isolated from a soda lake in China. Int J Syst Evol Microbiol 51, 1825-1829. 